\title{
Does Gender Heterogeneity Matters: The Moderating Role of Women Directors' Independence in the Indian Corporate Sector
}

\author{
Pradeep KAUR*, Poonam MAHAJAN**
}

Received: June 16, 2021. Revised: December 13, 2021. Accepted: December 15, 2021.

\begin{abstract}
This study aims to examine the moderating role of the independent status of women directors on the relationship between gender heterogeneity and firm value. The empirical analysis is performed on the panel data of BSE 100 companies for the period of 10 years from the year 2009 to 2018. Generalized Method of Moments is employed along with Fixed Effects Model while controlling for firm and board-specific variables to examine the relationship between gender heterogeneity and firm value. Moderation impact on this relationship is also analyzed empirically as well as graphically. Results show a negative impact of board gender heterogeneity on the value of a firm. Also, there is a negative moderation effect of women independent directors on the relationship between gender heterogeneity and firm value. Empirical findings of the present study contribute to the current discourse of gender heterogeneity and depict the Indian scenario of corporate boards in this context. This is the first study examining the moderating role of women independent directors on the relationship between board gender heterogeneity and the value of a firm in the Indian climate.
\end{abstract}

Keywords: Women independent directors, Tobin's Q, Board Gender Heterogeneity, Generalized Method of Moments, Moderating role

JEL Classification Codes : G34, J16, L25

UDC : 3341.02

DOI : https://doi.org/10.17015/ejbe.2021.028.05.

\footnotetext{
${ }^{*}$ Research Scholar, Guru Nanak Dev University, Amritsar, India. E-mail: pradeepusfs.rsh@gndu.ac.in ** Assistant Professor, Guru Nanak Dev University College, Narot Jaimal Singh, Pathankot, India. E-mail: poonam mcs@yahoo.co.in
}

Copyright @, 2021 Ala-Too International University. 


\section{Introduction}

The Corporate board was dominated by male directors all over the world, but legislation regarding the appointment of women directors in the last decade caused a dramatic shift in the composition of the board. The corporate world has become a platform for arguments and debates going all over the economies to arrive at a consensus on gender heterogeneity. Researchers made a business case for diversity which gave rise to many empirical studies in recent years. The results of these studies were extremely contrasting and inconclusive. Khan and Vieito (2013) analyzed the impact of CEO's gender on firm performance and concluded that when a firm has female CEO, then the risk level is radically reduced. Galia and Zenou (2013) and Midavaine et al. (2016) found a significant impact of gender heterogeneity in the examination of the various modules of board diversity with innovation. Fidanoski et al. (2014) also discovered that firms with gender heterogeneity do not lead to negative performance. These results encouraged some firms to add women directors on board while others remained unswerving on the homogeneity of corporate boards. These actions also inspired women to aspire to top positions in firms by shattering the glass ceiling and breaking gender stereotypes that seemed to be nonconformist before.

Norwegian government took the first initiative of introducing legislation for gender heterogeneity. It was followed by many European countries such as Italy, France, Spain, etc. Later, governments of developing countries also issued regulations for the same. India introduced new corporate legislation by amending its Companies Act, 2013 to make the presence of at least one woman director compulsory on Indian corporate boards. This mandatory regulation formed the foundation of a dramatic shift in the board composition of Indian firms. Clause 49 of SEBI was also amended based on the Indian Companies (Amendment) Act, 2013. But India's cultural environment was miles apart from developed countries. This decision only gave rise to the problem of tokenism in corporate industries. Many firms started appointing female directors just to comply with regulations, while some resorted to the employment of directors from their families themselves.

Discourse on gender heterogeneity and mandatory legislation pushed the presence of women directors to arise as a significant part of the business environment in the present era. After properly establishing a theoretical base, experiential studies are continuously undertaken to date to establish unanimity. It gave rise to many questions regarding the significance of gender heterogeneity.

Gender inequality and the wage gap are the major cause of concern in developing countries like India. The social, economic as well as cultural factors prevalent in the Indian economy might be the cause of such issues. Celebioglu (2017) highlighted this issue by examining women's employment in terms of gender inequality. Results show spatial relations between women's employment and the gender wage gap. The wage gap can be decreased by positively supporting women's employment. On the 
other hand, Khalifa and Zaki (2017) found that the relationship between perceived external salary equity and organizational support of employees is not moderated by their gender. India's social and cultural environments differ from that of developed nations which makes it necessary to evaluate this issue in the Indian context. Longitudinal study becomes essential to account for the impact of the Indian companies Regulation Act, 2013 on the firm value of a firm. The independence factor of women directors also needs to be factored in to summarize the current status of women directors in India.

This study aims to answer the leading questions of the corporate world. Does the presence of women directors add value to a firm? Does the independent status of women directors moderate the relationship between gender heterogeneity and firm value? The objectives have been formed after a comprehensive literature review and in light of the above research questions. This research contributes to inconclusive heterogeneity literature by analyzing the relationship between gender heterogeneity and firm value of BSE 100 companies for ten years from April 1, 2009, to March 31, 2018. It also estimates whether the independence of women directors moderates the relationship between gender heterogeneity and firm value.

The present study empirically investigates BSE 100 companies to fulfill the aforementioned objectives. Results show that the relationship between board heterogeneity and firm value is the negatively significant and independent status of women directors has a negative moderation impact on the relationship between gender heterogeneity and value of a firm.

The remainder of the paper is organized as follows. Section 2 provides a theoretical framework and hypothesis development. The sample selections, variables used in the study, and model specifications are then discussed in Section 3. Section 4 presents the findings of the study, while concluding remarks are mentioned in Section 5. Section 6 includes the implications of the study. The last section discusses the limitations of the study and its future scope.

\section{Theoretical Framework and Hypothesis Development}

Gender heterogeneity has a fair share of studies regarding its significance and its role in the corporate world. Some studies focus on the influence of gender on the combined decision-making ability of the board, while some focus on the final impact on firms' financial outcomes. This study is an attempt to examine the moderating role of the independent status of women directors on gender heterogeneity and firm value. The first section deals with the theories forming the theoretical construct of the present study, and the later section includes hypothesis development.

\subsection{Theories affecting board heterogeneity and performance of the firm}

Agency Theory: Jensen and Meckling (1976) developed this theory. It states that the board of directors acts on their self-interests at the expense of shareholders, which 
leads to higher agency costs. The studies conducted to analyze the relationship between gender heterogeneity and firm value majorly use agency theory as a base theory. It highlights that the foremost role of the board of directors is monitoring and controlling the firm's decisions which ultimately leads to higher firm value. The introduction of women directors on the corporate board increases the board effectiveness and independence of the board. Independent directors also lead to higher performance as there is a difference in viewpoint of inside and outside directors. It also states that gender heterogeneity reduces chances of information asymmetry and thus reduces agency costs. A further study was done by Abad et al. (2017) also concluded that gender heterogeneity leads to a reduction in information asymmetry.

Resource Dependency Theory: Pfeffer and Salancik (1978) stated that the firms require financial, physical, and informational resources which are obtained from the external environment. Firms that maintain diversity in corporate boards are most likely to acquire resources from the external environment. Carter et al. (2010) supported board gender heterogeneity. Resource Dependency Theory posits that there is a positive relationship between female board representation and the value of a firm as female directors bring diversity in ideas, knowledge, skills, which make all the difference in the decision-making process. Further, Adams and Ferreira (2009) stated that the value derived from female directors is the same as that of independent directors. It was empirically established that women directors have better attendance behavior and are most likely to be appointed to audit, nominating, and corporate governance committees. Additionally, there is a rapid increase in female consumers as well as a talent pool of female employees. So, it is appropriate that women directors should be appointed to address the current scenario (Burke \& Mattis, 2000). Based on these arguments, we conclude that resource-based perspectives promote board gender heterogeneity and recognize the importance of women directors in creating a difference.

Tokenism and Critical Mass Theory: Kanter (1978) advocated that the mere presence of one or two women directors does not influence the decisions of corporate boards. There is a need for three or more women directors for significant impact and inclusion, as posited by critical mass theory. Tokenism especially exists in countries where board gender heterogeneity is promoted by regulatory guidelines. The regulatory compulsion for the appointment of a female director can lead to a negative influence on financial performance as well as give birth to tokenism (Low et al., 2015). Nielsen and Huse (2010) and Ong (2019) concluded that critical mass is required for noteworthy influence; otherwise, the sole female director has an insignificant impact. This theory promotes the appointment of more women directors to achieve critical mass and reduce tokenism among corporate boards.

Gender Differences Theory: Gumperz and Cook-Gumperz (1983) depicted those men and women gender is like two separate cultures having differences in their emotional, motivational, and cognitive behavior. Differences in gender 
characteristics allow women directors to have different perspectives, different skill sets, and a broader understanding of customer base than their male counterparts. Nielsen and Huse (2010) provided evidence that women directors have a positive association with board development and help to reduce board conflict. As quoted by Burns (2012), when women directors are appointed in top management, then it also influences the leadership styles of their counterparts. So, this theory states that the companies should encourage more female directors on their boards to reap the benefits of gender differences.

\subsection{Hypothesis Development}

\subsubsection{Gender heterogeneity and firm performance}

An extant review of the literature revealed that women directors bring heterogeneity in board decision-making and improve a firm's performance. Ku Ismail and Abdul Manaf (2016) examined 127 Malaysian firms and deduced that investors favor women directors being appointed on board. Terjesen et al. (2016) conducted a multi-country study and empirically found out that women directors increase board effectiveness. Hafsi and Turgut (2013) analyzed diversity in boards with social performance and inferred a significant relationship. Other studies conducted in developed nations (Carter et al., 2003; Fidanoski et al., 2014; Kılıç \& Kuzey, 2016; Low et al., 2015) also discovered a significant positive relationship of gender heterogeneity on firm performance.

On the other hand, a study conducted by Rose (2015) on German companies from the year 2006 to 2014 illustrates the insignificant relationship between the presence of women directors and accounting measures of firm performance. Wang and Clift (2009) also examined the impression of gender and racial diversity on firm financial performance. It was ascertained that it does not affect corporate performance. Solakoglu and Demir (2016) investigated the relationship between female presence and firm performance during the year 2002 to 2006 and found that it is affected by some firm-specific factors but unearth no significant link between them. Chauhan and Dey (2017) and Kagzi and Guha (2018) concluded that the presence of women does not significantly affect the performance of a firm. Sanan (2016) found positive and significant results while using ordinary least squares (OLS) and fixed effects (FE) estimation models, but reverse results were attained when superior Arellano Bond estimation was employed. Furthermore, many studies have been carried out to solve this research issue in developed nations, but there is a dearth of studies on this intricate topic in developing nations like India.

The following alternative hypothesis has been developed based on the review of the literature and tested by the employment of the Generalized Method of Moments (GMM).

H1: The presence of women directors on the Indian corporate board negatively influences the value of a firm. 


\subsubsection{Moderating effect of independence of the female director}

Erhardt et al. (2003) used hierarchical regression analysis and proved that gender representation on board improves the organizational performance of the firm. On the contrary, Wang and Clift (2009) and Mirza et al. (2012) found that female directors do not have a significant impact on the performance of a firm. Baron and Kenny (1986) stated that moderators could be introduced when there is a weak or inconsistent relationship between independent and outcome variables. Terjesen et al. (2016) performed a multi-country study on gender heterogeneity and concluded that gender diversified board and independence go hand in hand. The positive impact of independent directors on gender diversified boards was also established. There are only a few studies conducted in this context. So, the following hypothesis is framed to analyze the impact of the presented moderating variable on gender heterogeneity and firm value relationship.

$\mathrm{H}$ 2: Women independent directors moderate the relationship between gender heterogeneity and firm value.

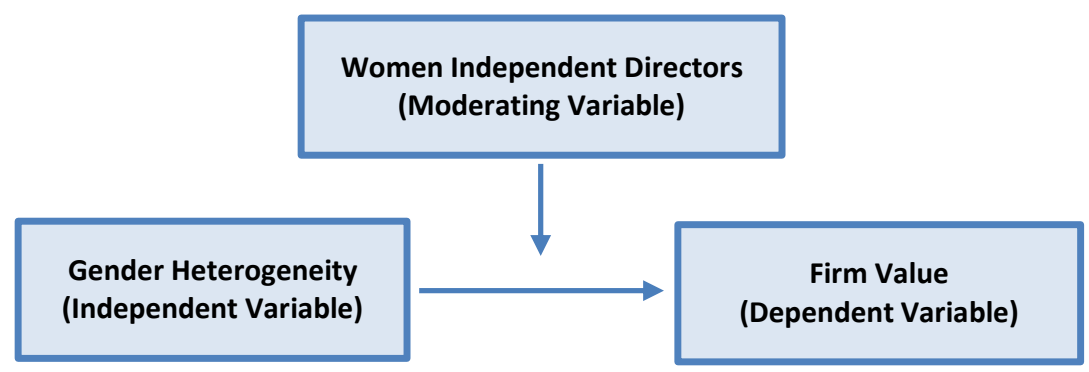

Figure 1. Conceptual framework

\section{Research Methodology}

\subsection{Sample Selection}

The sample of the present study comprises of BSE top 100 Companies as of July 2, 2019 , based on their size measured by market capitalization and liquidity. The secondary data related to the presence of women directors on board is obtained from annual reports of selected companies. The firms' attributes-related data has been collected from the Ace Equity database (a corporate database that provides the latest historical, financial, and non-financial information on listed and unlisted entities in India). This led to a final filtered sample of 640 firm-year observations comprising of 64 firms for ten years from the years 2009 to 2018. All the banks and financial institutions were removed from datasets as these are liable under different regulations and governed by different authorities. Accessibility of annual reports was 
Does Gender Heterogeneity Matters: The Moderating Role of Women Directors'...

another parameter of sample selection. Final observations were found to be 639 for moderation analysis and 630 for direct relationship after the above filtrations.

\subsection{Variables used in the study}

\subsubsection{Dependent variable}

Tobin's $Q$ Ratio: Accounting and market-based measures are usually used as proxies for the financial performance of firms. Return on assets (ROA), return on sales (ROS), and return on capital employed (ROCE) are some of the accounting-based measures popularly used by researchers (Mahadeo et al., 2012; Rose et al., 2013).

This study employs Tobin's $Q$ as it captures the prospects of the firm and its intangible assets (Bøhren \& Strøm, 2010; Terjesen et al., 2016). It is a more forwardlooking approach but also considers historical value, which makes it a more efficient and appropriate proxy.

\subsubsection{Independent variable}

Board gender heterogeneity: The proportion of women directors (PFD): Board gender heterogeneity is represented by taking a proportion of women directors on the corporate board. It is a proxy for the representation of women directors (Adams \& Ferreira, 2009; Erhardt et al., 2003).

\subsubsection{Moderating variable}

Independent status of women directors (PFID): The proportion of women independent directors is used as moderating variable for the present study. It is measured by scaling the number of women independent directors on board by total board size.

\subsubsection{Control variables}

\section{Board related variable}

Total board size (TBD): Board size is recorded from the board composition of the firm reported in the annual reports of a company as of March 31 of each financial year. Some studies concluded that large boards could create coordination problems as it is difficult to account decisions of each director and arrive at a consensus. The result of Chauhan and Dey (2017) is consistent with the aforementioned argument, but on the other hand, some studies reported that there is an inverse relationship between board size and the value of a firm (Bhagat \& Bolton, 2008; Mak \& Kusnadi, 2005; Yermack, 1996).

The proportion of independent directors (PID): It is computed as a proportion of independent directors on the corporate board. Terjesen et al. (2016) concluded that the independence of directors is positively significant when boards are more diversified, but the same will be detrimental when there are only one or two women directors. Adams and Ferreira (2009) found mixed results based on the estimation 
method selected concerning firm performance. The size of independent directors (ID) is also controlled by taking the number of independent directors present onboard for moderation effect analysis.

CEO Duality (CEOD): Categorical variable is used for this representation. It takes a value of 'one' when both position of CEO and chairman is held by the same individual and 'zero' otherwise. Bhagat and Bolton (2008) and Terjesen et al. (2016) found out that CEO duality leads to lower valuations of the firm.

Firm-specific variables

Firm age ( $A G E$ ): Natural logarithm of the total number of years of selected Indian companies starting from the firm's incorporation year till March 31, 2018, has been taken as firm age (Chauhan \& Dey, 2017; Kagzi \& Guha, 2018). Bonn (2004) concluded that age has no significant impact on firm performance while employing OLS.

Firm size (SIZE): Natural logarithm of total assets is used to compute the firm size of selected Indian firms (Kagzi \& Guha, 2018). A high degree of skewness is found in firm size. This is corrected by taking its natural logarithm (Sanan, 2016).

\subsection{Model specification}

The following model is proposed to study the impact of the presence of women directors on the board on the value of a firm while controlling for the board and firmspecific variables.

$$
\begin{aligned}
\text { Tobin's }_{i t}=\beta_{0} & +\beta_{1} \text { proportion offemale director }_{i t}+\beta_{2} \text { firm age }_{i t} \\
& +\beta_{3} \text { firmsize }_{i t}+\beta_{5} \text { board size }_{i t} \\
& +\beta_{6} \text { proportion of independent director }_{i t}+\beta_{7} \text { CEO duality } \\
& +\gamma_{i}+\delta_{t}+\varepsilon_{i t}
\end{aligned}
$$

Where Tobin's Qit is the sum of the market value of equity and book value of debt scaled by the book value of assets of the company i for year t. $\beta$ _ 0 is the intercept of the equation. The proportion of female directors (PFD) is a time-varying explanatory variable with $\beta \_1$ as the corresponding coefficient vector while firm age (AGE), firm size (SIZE), board size (TBD), the proportion of independent director (PID), and CEO duality (CEOD) are control variables. $y$ i is unobserved heterogeneity term constant over time, $\delta t$ is unobserved heterogeneity term constant over cross-section units, and $\varepsilon_{-}$it shows the error term of the specified model.

Estimation equation - GMM-Difference

$d(T O B I N Q)=\alpha+c(1) * d\left(T O B I N Q_{i t-1}\right)-c(2) * d\left(P F D_{i t}\right)+c(3) * d\left(P I D_{i t}\right)+c(4) * d\left(T B D_{i t}\right)-$ $c(5) * d\left(C E O D_{i t}\right)+c(6) * d\left(S I Z E_{i t}\right)-c(7) * d\left(A G E_{i t}\right)+\varepsilon_{i t}$

This equation is used to analyze the impact of the proportion of female directors on Tobin's $Q$ with lagged dependent variable along with corresponding coefficients. The difference of variables is used to estimate the output in this specific GMM model. 
Does Gender Heterogeneity Matters: The Moderating Role of Women Directors'...

Estimation equation - GMM-System

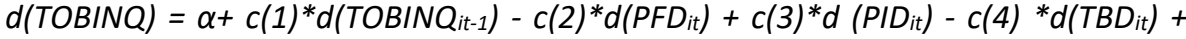
$c(5) * d\left(C E O D_{i t}\right)+c(6) * d\left(S I Z E_{i t}\right)+c(7) * d\left(A G E_{i t}\right)+\varepsilon_{i t}$

TOBINQ $=\alpha+c(8) * T O B I N Q_{i t-1}-c(9) * P F D_{i t}+c(10) * P I D_{i t}-c(11) * T B D_{i t}+c(12)^{*} C E O D_{i t}+$ $c(13) * S I Z E_{i t}+c(14)^{*} A G E_{i t}+\varepsilon_{i t}$

GMM-System combines regressions of level and first differences of the variable. The first equation deals with differences of variables, while the second equation includes variables at the level.

\section{Analysis Results}

\subsection{Descriptive Statistics}

Table 1 shows the descriptive statistics of variables for the period of 10 years from the year 2009 to 2018. The mean value of Tobin's $Q$ is 3.20; the Minimum is 0.37 while the maximum reaches up to 17.96 . It shows the majority of firms in our sample are profitable firms. But on the other hand, presence of female directors on average is only $9 \%$ percent. On the contrary, independent directors constitute $54 \%$ of the board. One of the reasons for these unexpected descriptive results is those female directors are usually appointed as independent directors to serve two purposes with one appointment. Scrutinization of annual reports showed that vacancy created by a male director is often filled by employing another male director, whereas female directors are appointed as a token to serve the corporate regulatory requirement of India as specified in the Companies Act, 2013 and usually make an addition to existing board size.

\section{Table 1. Descriptive Information}

\begin{tabular}{lccccc}
\hline Variables & $\mathbf{N}$ & Minimum & Maximum & Mean & Standard Deviation \\
\hline TOBINQ & 640 & 0.37 & 17.96 & 3.20 & 2.71 \\
\hline PFD & 640 & 0.00 & 0.44 & 0.09 & 0.08 \\
\hline TBD & 640 & 6.00 & 25.00 & 11.77 & 2.82 \\
\hline PID & 640 & 0.00 & 1.21 & 0.54 & 0.14 \\
\hline CEOD & 640 & 0.00 & 1.00 & 0.20 & 0.40 \\
\hline SIZE & 640 & 6.00 & 13.23 & 10.32 & 1.21 \\
\hline AGE & 640 & 0.69 & 4.71 & 3.61 & 0.60 \\
\hline
\end{tabular}

\subsection{Correlation Analysis}

Table 2 shows that there is no multicollinearity as the correlation between independent variables does not exceed 0.80 . It shows that independent variables are weakly correlated. 
Pradeep KAUR \& Poonam MAHAJAN

Table 2. Correlation Matrix

\begin{tabular}{lcccccc}
\hline & TOBIN's Q & PFD & PID & TBD & SIZE & AGE \\
\hline TOBIN's Q & 1.0000 & & & & & \\
\hline PFD & $0.10982^{* * *}$ & 1.0000 & & & & \\
\hline PID & -0.02336 & $0.07293^{*}$ & 1.0000 & & & \\
\hline TBD & $-0.09783^{* * *}$ & -0.01727 & 0.05157 & 1.0000 & & \\
\hline SIZE & $0.16094^{* * *}$ & $0.14026^{* * *}$ & $0.1896^{* * *}$ & $0.31991^{* * *}$ & 1.0000 & \\
\hline AGE & -0.02289 & 0.01343 & $0.1280^{* * *}$ & $0.06784 *$ & $0.10470^{* * *}$ & 0.000 \\
\hline$*, * *, * * *$ & statistically significant at $10 \%, 5 \%$ and $1 \%$ respectively. & & &
\end{tabular}

\subsection{Interpretation of Results}

\subsubsection{Relationship between Gender Heterogeneity and Firm Value}

Table 3 explains the results of regression analysis. OLS analysis shows that the presence of a woman director on the Indian board has a positive and significant influence on Tobin's $Q$. The control variables like independence and firm age are not found to be significant, while total board size $(-1 \%)$ and CEO duality $(-1 \%)$ and size $(+1 \%)$ are found to be significant with firm performance. Total board size ( $p$ value $=0.0021$ ) is also positively significant, which shows that the larger the board size, the higher the firm performance (Chauhan \& Dey, 2017).

Table 3. Regression Analysis with Tobin's Q (with different methodologies)

\begin{tabular}{lcccc}
\hline Variables & OLS & FE with SE & GMM-DIFF & GMM-SYS \\
\hline TOBIN's Q(-1) & -- & -- & $0.17538^{* * *}$ & $0.97717^{* * *}$ \\
\hline CONSTANT & 0.02143 & $-6.07036^{* * *}$ & 58.3326 & -2.0714 \\
\hline PFD & $3.28956^{* * *}$ & $-0.93658^{* *}$ & $-0.49350^{* *}$ & -1.4271 \\
\hline PID & -0.73669 & 0.02294 & 0.07702 & 1.1885 \\
\hline TBD & $-0.14235^{* * *}$ & $0.07928^{* * *}$ & $0.01714^{* *}$ & -0.097176 \\
\hline CEOD & $-1.99230^{* * *}$ & 0.08286 & -0.11053 & 0.14243 \\
\hline SIZE & $0.59629^{* * *}$ & $1.68349^{* * *}$ & $1.54734^{* * *}$ & 0.22611 \\
\hline AGE & -0.21901 & $-2.48566^{* * *}$ & $-3.03017^{* * *}$ & 0.15332 \\
\hline Adjusted & 0.13753 & 0.852914 & & -- \\
R- Squared & -- & -- & 0.083108 & -- \\
\hline Hansen & -- & -- & -- & 0.3148 \\
J- Statistic & -- & -- & 0.0053 & 0.0000 \\
\hline $\begin{array}{l}\text { Sargan Over- } \\
\text { Identification Test }\end{array}$ & -- & -- & 0.0004 & 0.0000 \\
\hline Wald X & -- & -- & 0.2593 & 0.0877 \\
\hline AR(1) & 630 & 630 & 630 & 567 \\
\hline AR(2) & & &
\end{tabular}


Hausman test specifies that the fixed effect model is appropriate for the selected model (Wooldridge, 2012). Results show that the presence of women directors has a negative and significant impact on the value of the firm (Adams \& Ferreira, 2009). Independence and CEO duality are not significant, while other control variables such as firm size $(+, 0.0000)$, firm age $(-, 0.0000)$, total board size $(+, 0.0002)$ are found to be significant at a $1 \%$ level of significance.

Dynamic panel data estimator (GMM-difference): GMM estimator is used to compute dynamic panel data models (Kagzi \& Guha, 2018). A direct test of secondorder residual serial coefficient, a Sargan test of over-identifying restrictions, and Hausman specification are performed to check the validity of instruments as suggested by Arellano and Bond (1991) in their study. Results of J-Hansen statistic shows that instrumental variable, i.e., lagged dependent variable, is valid. Arellanobond serial correlation test states that null hypothesis is rejected in AR (1), which is common when a lagged variable is taken as an instrumental variable for GMM estimation, but the value of $A R(2)$ should be more than $10 \%$, thus accepting the null hypothesis. The null hypothesis states that there is no serial correlation in the model. It shows that the error term of the model specified is not serially correlated, which proves that there are enough lags of the instrumental variables to control for the dynamic relationship in the model. Aforesaid, the model is found suitable to address endogeneity, reverse causality, and the dynamic nature of the variable selected.

GMM model shows that representation of women on board has a significant but negative impact on the value of the firm (Sanan, 2016). These results are not unsurprising for a patriarchal society like India, where women directors are appointed as tokens and mostly appointed to fulfill legal requirements. Independence and CEO duality is not significant while firm age (- $1 \%)$, firm size (+ $1 \%)$ and total board size $(+5 \%)$ is significant in GMM estimation. It encapsulates that the present business environment demands a balanced, diverse board to ensure growth in the value of a firm. So, it shows that $\mathrm{H} 1$ is accepted at a $5 \%$ level of significance for the present study.

This study also employs GMM- System to analyze the impact of the proportion of women directors on the value of a firm. Even though the results show an insignificant relationship, but the negative relationship remains consistent in both GMM estimation methods. Variation in results of GMM estimations is because of different model specifications. GMM-difference model is based on the difference of variables employed while GMM-System uses regressions of level and first differences of the variables.

It presents that the actual influence of women directors will only be realized when the appointment of women directors is based on skill set and qualifications, and the issue of tokenism will be resolved. Various resources brought by women directors need to be utilized by giving them the opportunity to be heard. 


\subsubsection{Moderation effect of Women directors Independence on Board Heterogeneity and Firm Value}

Moderation analysis is performed through PROCESS macro for moderation by Hayes (2013). This analysis is performed by taking GD*PFID as an interaction variable. The interaction variable is the interplay of the presence of women directors (GD) and the proportion of female independent directors (PFID).

The result of Table 4 shows that the independent variable and gender heterogeneity have a significant effect on Tobin's $Q$, but moderating variable (proportion of women independent directors) is insignificant. Whereas the interaction term, GD*PFID, is negatively significant $(0.0519)$ at $10 \%$. It shows that a smaller number of female independent directors are more advantageous for firm performance. The more independent status of female directors may adversely affect the firm value. Among the covariates, the size of independent directors, CEO duality, and size of the firm is significant. Independent directors and CEO duality are also negatively significant. While the firm size has a positive effect on the relationship, but other aspects depict that the female directors should be entrusted with independent status based on their knowledge and experience. Women independent directors should not only be appointed to fulfill regulatory requirements. Government should work with the corporate sector to establish training programs for women leaders. Thus, they can fulfill the responsibility entrusted to them and surpass their status as a token (Pathak \& Purkayastha, 2016).

Table 4. Linear models of predictors of Tobin's $Q$ showing moderation effect

\begin{tabular}{lccc}
\hline Variable & Coeff. & S. E. & t \\
\hline constant & -0.0528 & 1.0240 & -0.0516 \\
\hline GD & $3.6299^{* * *}$ & 1.5055 & 2.4111 \\
\hline PFID & 0.7389 & 1.1266 & 0.6559 \\
\hline GD*PFID & $-14.8828^{*}$ & 7.6408 & -1.9478 \\
\hline TBD & -0.0511 & 0.0499 & -1.0250 \\
\hline ID & $-0.1090^{*}$ & 0.0578 & -1.8853 \\
\hline CEOD & $-1.660^{* * *}$ & 0.2580 & -6.4350 \\
\hline AGE & -0.1385 & 0.1721 & -0.8047 \\
\hline SIZE & $0.5430^{* * *}$ & 0.0836 & 6.4928 \\
\hline R-Sq & 0.1333 & & \\
\hline Change in R-Sq & 0.0052 & & \\
\hline Obs. & 639 & & \\
\hline$*, * * * *$ & &
\end{tabular}




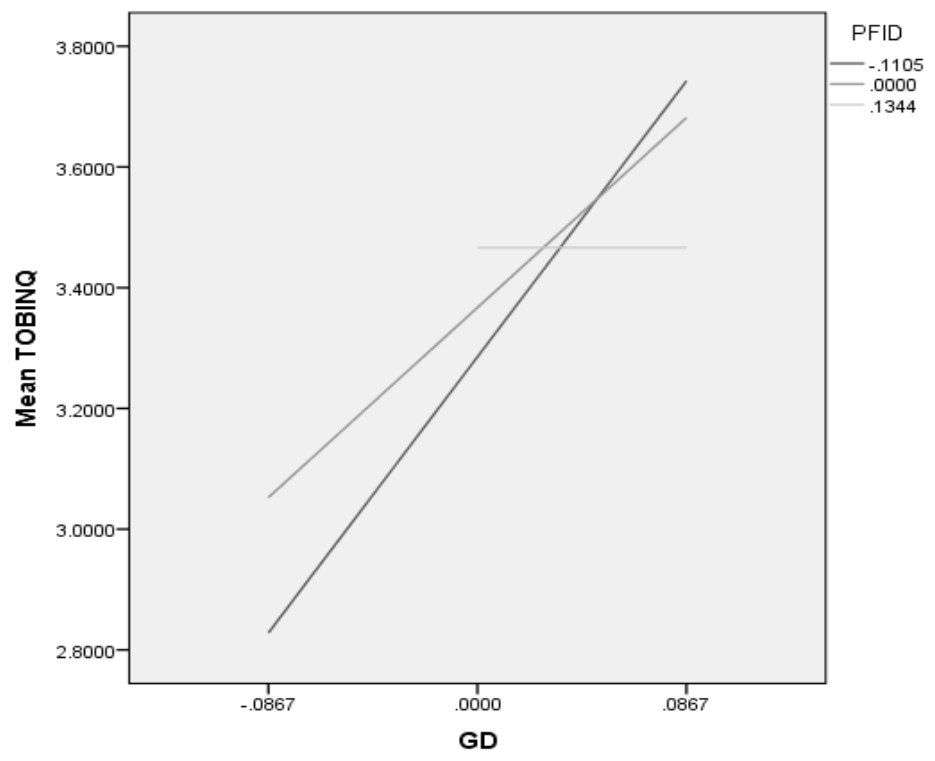

Figure 2. Moderation effect of the proportion of female independent directors on the relationship between gender heterogeneity and firm value

The graph in Figure 2 is used to show conditional effects of focal predicate at values of PFID (moderating variable). It takes different values of the proportion of female independent directors (PFID). It computes the effect (b) and its significance for the relationship between GD and Tobin's $Q$.

- When PFID is low (to be precisely at -0.1105$)$, then effect $(b, 5.2751)$ is significant $(0.0018)$ at $1 \%$.

- At the mean value of PFID (0.0000), there is a significant $(0.0162)$ positive relationship between gender heterogeneity, GD, and Tobin's $Q$ at $1 \%$, and effect (b) is 3.6299.

- When PFID is high (0.1344), then effect (b) is 1.6294 , and there is an insignificant (0.3840) positive relationship between GD and Tobin's $Q$.

These results explain that the relationship between GD and Tobin's $Q$ only emerges when less or the average number of female directors are present in corporate boards. Therefore, $\mathrm{H} 2$ is accepted at a $10 \%$ level of significance, though; it has a negative moderation effect.

\section{Discussion and Conclusion}

In a patriarchal society like India questions regarding, the impact of women's presence on corporate board has started to surface during the last decade. The 
compulsory appointment of at least a woman director on board by the Companies (Amendment) Act, 2013 sped up the heterogeneity of the board of Indian firms. This study was done to contribute to a convoluted debate of "Does Gender Heterogeneity really matters?". Consistent results for the fixed effect model with standardized errors and GMM estimation were found. It was established that there is a negative impact of the presence of women directors on the value of firms. The moderation effect of the independent status of women directors is also analyzed and found to be negatively significant. It was concluded that many Indian firms are employing women directors to fulfill only regulations. Women directors are usually appointed as independent directors to fill the required quorum of independent directors as well as oblige with mandatory regulation of at least one woman director stipulated by the Indian Companies (Amendment) Act, 2013. The vast majority of firms employed women from their families to uphold this compulsory regulation. Only a few firms like Apollo hospitals enterprises limited established a superior example for others by maintaining diversified boards which have a critical mass of female directors. The presence of tokenism in the present environment explains the negative impact of the presence of women directors on the value of a firm. Kanter (1978) also specified that 'women directors do not have to work hard to get their presence noticed, but they have to work hard to get their achievements noticed.'

Paradoxically, women directors also feel that they have to do well to get noticed but are terrified that if they do so, then their success will not be rewarded and thus prefer to keep to themselves. Due to the minority on board, women hesitate to give their opinion, and they do not seem to have weighed in on important decisions taken by the board. It specifies that resource dependence theory is not followed. Resources brought by women directors are not utilized properly. Saundarya Rajesh, FounderAVTAR Group, one of India's foremost Diversity and Inclusion consulting firms, said:

'The inclusion of women directors on boards has not found its full value, simply because even today, many appointees are family members of the owners, whose one qualification of being a woman does not really add value to the organization's problem-solving capabilities or creative thinking,' (Bhattacharyya, 2018).

The present study contributes to the existing literature on gender heterogeneity by establishing that presence of women directors has a negative impact on the value of a firm and points out the extremity of the situation prevailing in developing countries like India. It demonstrates a negative and significant moderation effect of the proportion of women independent directors. Finally, it concludes that qualities, skills, knowledge, experience, and problem tackling abilities are important elements to be considered for the appointment of directors. It is a social responsibility of corporate firms and a prerequisite for corporate governance regulators to establish proper criteria for the appointment of corporate directors. Indian regulators recently established the Online Proficiency Self-Assessment test for independent directors. India is on the path of gender heterogeneity and to create a difference on a world platform. 
Does Gender Heterogeneity Matters: The Moderating Role of Women Directors'...

\section{Implications of the study}

This study has the following implications in the contemporary competitive business scenarios:

Industry: Industries should formulate policies for welcoming organization culture to promote gender heterogeneity and remove the issue of tokenism. Steps should also be taken to shatter the glass ceiling encapsulating the industry even in the modern era. This study concludes that there is a need for a pre-defined skill set for the appointment of directors and change in the organization environment to engulf gender heterogeneity.

Academicians: Gender heterogeneity is a thriving opportunity for academicians to increase the scope of the current study and to explore the grey areas of this concept. Various authors argue that different methodologies and different variables provide contrasting findings. This argument can be resolved by employing all viable methodologies. Here an attempt is made to cover OLS, fixed effect model with standardized errors, and superior Arellano-Bond GMM estimation. The relationship impact of other moderating and mediating variables can also be studied. The present study covered the moderating impact of women independent directors.

Society: Many studies gave positive and significant results of the presence of women directors on financial performance. But some provided contrasting results, including the present study. There is a need to explore the full potential of ideas, experiences, and skills of women directors in a conventional society like India. There is a need for society to provide full encouragement and support to achieve this motto. Women's representation on Australian boards changed from $8 \%$ to $28.5 \%$ in the span of 10 years, and society played a big role in achieving these statistics.

Regulatory Authorities: Indian regulators amended the Indian Companies Act, 2013 to make at least the presence of one woman director mandatory on the corporate board. Norwegian parliament made it compulsory that the board of all publicly traded and public limited companies must have at least 40 percent women representation. French and Italian companies also have a minimum of three directors on board as gender quotas were also implemented in these countries. According to the catalyst report 2018 , only $33 \%$ of US boards had at least three women directors on board in the year 2018. In light of new researches, steps can be taken to increase women's representation on corporate boards similar to regulations introduced by Norway, France, Italy, and the USA. Descriptives are the witness of tokenism and the extreme problem of the glass ceiling existing in Indian society. There is a need for strict regulation to employ not only woman directors but skilled and deserving women directors. India has taken various steps to formulate a qualifying procedure for the appointment of independent directors. 


\section{Limitations and Future Scope}

The study shows the present situation in Indian corporate boards and provides empirical evidence for it, but it also has some limitations. Firstly, this study is only concentrated on one dimension of board diversity, i.e., gender heterogeneity. This paper examines the impact of the presence of women directors on firm performance and the moderation effect of women independent directors. To properly analyze, heterogeneity of the board and its impact on the board, other demographic aspects have to be required to be taken into consideration. The effects of another dimension are not included in the study would be unjustifiably ascribed to the dimension of gender heterogeneity being studied (Hutzschenreuter \& Horstkotte, 2013).

Secondly, the current study is conducted on the BSE100 index, which consists of the top 100 companies based on their market capitalization and liquidity. It explains only larger Indian firms. Even though the size is controlled, but there is a need to analyze the impact of the presence of women directors on firm value in the case of small firms also.

Tobin's $Q$ is taken as a proxy for the value of the firm as it is a market-based measure and efficient indicator of firm performance, while some studies used ROA, ROE, etc. Different results were obtained based on different proxies used. Rose et al. (2013) found no significant relationship between the presence of women directors on corporate board and ROA, ROE, and ROCE taken as proxies for firm performance. Future studies can be conducted to analyze the impact of gender heterogeneity on shareholder value and other financial outcomes of corporate firms.

\section{References}

Abad, D., Lucas-Pérez, M. E., Minguez-Vera, A., \& Yagüe, J. (2017). Does Gender Diversity on Corporate Boards Reduce Information Asymmetry in Equity Markets? BRQ Business Research Quarterly, 20(3), 192-205. https://doi.org/10.1016/j.brq.2017.04.001

Adams, R. B., \& Ferreira, D. (2009). Women in the boardroom and their impact on governance and performance. Journal of Financial Economics, 94(2), 291-309. https://doi.org/10.1016/i.jfineco.2008.10.007

Arellano, M., \& Bond, S. (1991). Some Tests of Specification for Panel Data: Monte Carlo Evidence and an Application to Employment Equations. The Review of Economic Studies, 58(2), 277-297. https://doi.org/10.2307/2297968

Baron, R. M., \& Kenny, D. A. (1986). The moderator-mediator variable distinction in social psychological research: Conceptual, strategic, and statistical considerations. Journal of Personality and Social Psychology, 51(6), 1173-1182. https://doi.org/10.1037/0022$\underline{3514.51 .6 .1173}$

Bhagat, S., \& Bolton, B. (2008). Corporate governance and firm performance. Journal of Corporate Finance, 14(3), 257-273. https://doi.org/10.1016/j.jcorpfin.2008.03.006

Bøhren, $\varnothing$ y., \& Strøm, R. $\varnothing$. (2010). Governance and Politics: Regulating Independence and Diversity in the Board Room. Journal of Business Finance \& Accounting, 37(9-10), 1281-1308. https://doi.org/10.1111/j.1468-5957.2010.02222.x 
Does Gender Heterogeneity Matters: The Moderating Role of Women Directors'...

Bonn, I. (2004). Board Structure and Firm Performance: Evidence from Australia. Journal of Management \& Organization, 10(1), 14-24. https://doi.org/10.5172/imo.2004.10.1.14

Burke, R. J., \& Mattis, M. C. (Eds.). (2000). Women on Corporate Boards of Directors: International Challenges and Opportunities (Vol. 14). Springer Netherlands. https://doi.org/10.1007/978-90-481-3401-4

Burns, J. M. (2012). Leadership. Open Road Media.

Carter, D. A., D'Souza, F., Simkins, B. J., \& Simpson, W. G. (2010). The Gender and Ethnic Diversity of US Boards and Board Committees and Firm Financial Performance. Corporate Governance: An International Review, 18(5), 396-414. https://doi.org/10.1111/j.14678683.2010.00809.x

Carter, D. A., Simkins, B. J., \& Simpson, W. G. (2003). Corporate Governance, Board Diversity, and Firm Value. Financial Review, 38(1), 33-53. https://doi.org/10.1111/1540-6288.00034

Celebioglu, F. (2017). Women Employment in terms of Gender Inequality across the Provinces of Turkey. Eurasian Journal of Business and Economics, 10(19), 61-80. https://doi.org/10.17015/ejbe.2017.019.04

Chauhan, Y., \& Dey, D. K. (2017). Do female directors really add value in Indian firms? Journal of Multinational Financial Management, 42-43, 24-36. https://doi.org/10.1016/i.mulfin.2017.10.005

Erhardt, N. L., Werbel, J. D., \& Shrader, C. B. (2003). Board of Director Diversity and Firm Financial Performance. Corporate Governance: An International Review, 11(2), 102-111. https://doi.org/10.1111/1467-8683.00011

Fabrice Galia \& Emmanuel Zenou. (2013). Does board diversity influence innovation? The impact of gender and age diversity on innovation types. 35th Druid Celebration Conference 2013, Barcelona, Spain.

Fidanoski, F., Simeonovski, K., \& Mateska, V. (2014). The Impact of Board Diversity on Corporate Performance: New Evidence from Southeast Europe. Advances in Financial Economics, 17, 81-123. https://doi.org/10.1108/S1569-373220140000017003

Gumperz, J. J., \& Cook-Gumperz, J. (1983). Introduction: Language and the communication of social identity. In J. J. Gumperz (Ed.), Language and Social Identity (1st ed., pp. 1-21). Cambridge University Press. https://doi.org/10.1017/CB09780511620836.003

Hafsi, T., \& Turgut, G. (2013). Boardroom Diversity and its Effect on Social Performance: Conceptualization and Empirical Evidence. Journal of Business Ethics, 112(3), 463-479. https://doi.org/10.1007/s10551-012-1272-z

Hayes, A. F. (2013). Introduction to mediation, moderation, and conditional process analysis: A regression-based approach. (2013th ed.). Guilford Press. https://psycnet.apa.org/record/2013-21121-000

Hutzschenreuter, T., \& Horstkotte, J. (2013). Performance effects of top management team demographic faultines in the process of product diversification. Strategic Management Journal, 34(6), 704-726. https://doi.org/10.1002/smj.2035

Jensen, M. C., \& Meckling, W. H. (1976). Theory of the firm: Managerial behavior, agency costs and ownership structure. Journal of Financial Economics, 3(4), 305-360. https://doi.org/10.1016/0304-405X(76)90026-X 
Kagzi, M., \& Guha, M. (2018). Does board demographic diversity influence firm performance? Evidence from Indian-knowledge intensive firms. Benchmarking: An International Journal, 25(3), 1028-1058. https://doi.org/10.1108/BIJ-07-2017-0203

Kanter, R. M. (1978). Men and Women of the Corporation. The Journal of Applied Behavioral Science, 14(2), 247-250. https://doi.org/10.1177/002188637801400208

Khalifa, M. H., \& Zaki, R. (2017). Gender and the Perceived Equity-Perceived Organizational Support Link in Egypt. Eurasian Journal of Business and Economics, 10(20), 17-32. https://doi.org/10.17015/ejbe.2017.020.02

Khan, W. A., \& Vieito, J. P. (2013). Ceo gender and firm performance. Executive Compensation, 67, 55-66. https://doi.org/10.1016/j.jeconbus.2013.01.003

Kılıç, M., \& Kuzey, C. (2016). The effect of board gender diversity on firm performance: Evidence from Turkey. Gender in Management: An International Journal. https://doi.org/10.1108/GM-10-2015-0088

Ku Ismail, K. N. I., \& Abdul Manaf, K. B. (2016). Market reactions to the appointment of women to the boards of Malaysian firms. Journal of Multinational Financial Management, 36, 75-88. https://doi.org/10.1016/i.mulfin.2016.04.004

Lee L. O. (2019). Gender diversity and financial implications: Endogeneity issues and critical mass of females on corporate boards. [Bond Business School]. https://research.bond.edu.au/en/studentTheses/gender-diversity-and-financialimplications-endogeneity-issues-an

Low, D. C. M., Roberts, H., \& Whiting, R. H. (2015). Board gender diversity and firm performance: Empirical evidence from Hong Kong, South Korea, Malaysia and Singapore. Pacific-Basin Finance Journal, 35(PA), 381-401. https://doi.org/10.1016/i.pacfin.2015.02.008

Mahadeo, J. D., Soobaroyen, T., \& Hanuman, V. O. (2012). Board Composition and Financial Performance: Uncovering the Effects of Diversity in an Emerging Economy. Journal of Business Ethics, 105(3), 375-388. https://doi.org/10.1007/s10551-011-0973-z

Mak, Y. T., \& Kusnadi, Y. (2005). Size really matters: Further evidence on the negative relationship between board size and firm value. Pacific-Basin Finance Journal, 13(3), 301-318. https://doi.org/10.1016/i.pacfin.2004.09.002

Midavaine, J., Dolfsma, W., \& Aalbers, R. (2016). Board diversity and R\&D investment. Management Decision, 54(3), 1-16. https://doi.org/10.1108/MD-09-2014-0574

Mirza, H. H., Andleeb, S., \& Ramzan, F. (2012). Gender Diversity and Firm Performance: Evidence from Pakistan. Journal of Social and Development Sciences, 3(5), 161-166. https://doi.org/10.22610/jsds.v3i5.698

Nielsen, S., \& Huse, M. (2010). The Contribution of Women on Boards of Directors: Going beyond the Surface. Corporate Governance: An International Review, 18(2), 136-148. https://doi.org/10.1111/j.1467-8683.2010.00784.x

Pathak, A. A., \& Purkayastha, A. (2016). More women on Indian boards: Moving beyond mere regulations and tokenism. Strategic Direction, 32(3), 13-15. https://doi.org/10.1108/SD-052015-0081

Pfeffer, J., \& Salancik, G. R. (1978). The external control of organizations: A resource dependence perspective. New York: Harper \& Row. https://lib.ugent.be/catalog/rug01:001376664 
Does Gender Heterogeneity Matters: The Moderating Role of Women Directors'...

Bhattacharyya, R. (2018, February 19). Woman director: Gender diversity on boards improves, but more ground needs to be covered: Experts. The Economic Times. https://economictimes.indiatimes.com/news/company/corporate-trends/gender-diversityon-boards-improves-but-more-ground-needs-to-be-coveredexperts/articleshow/62988324.cms

Rose, C., Munch-Madsen, P., \& Funch, M. (2013). Does board diversity really matter? Gender does not, but citizenship does. International Journal of Business Science \& Applied Management (IJBSAM), 8(1), 16-27.

Rose, M. (2015). The impact of board diversity in board compositions on firm financial performance of organizations in Germany. (Bachelor's thesis, University of Twente)

Sanan, N. K. (2016). Board gender diversity and firm performance: Evidence from India. Asian Journal of Business Ethics, 5(1), 1-18. https://doi.org/10.1007/s13520-016-0050-x

Solakoglu, M. N., \& Demir, N. (2016). The role of firm characteristics on the relationship between gender diversity and firm performance. Management Decision, 54(6), 1407-1419. https://doi.org/10.1108/MD-02-2015-0075

Terjesen, S., Couto, E. B., \& Francisco, P. M. (2016). Does the presence of independent and female directors impact firm performance? A multi-country study of board diversity. Journal of Management \& Governance, 20(3), 447-483. https://doi.org/10.1007/s10997-014-9307-8

Wang, Y., \& Clift, B. (2009). Is there a "business case" for board diversity? Pacific Accounting Review, 21(2), 88-103. https://doi.org/10.1108/01140580911002044

Wooldridge, J. (2012). Introductory Econometrics: A Modern Approach (5th edition). SouthWestern College Publishing.

Yermack, D. (1996). Higher market valuation of companies with a small board of directors. Journal of Financial Economics, 4O(2), 185-211. https://doi.org/10.1016/0304-405X(95)00844$\underline{5}$ 